\title{
AUTHOR INDEX VOLUME 2 (1984)
}

(The issue number is given in front of the page numbers)

Armstrong, C.J., The design and implementation of a microcomputer teaching package for online bibliographic searching

(1) $35-42$

Broadbent, M., Information management and educational pluralism

(3) $209-227$

Bunch, A.J., Education and training for health care librarianship

(1) $19-27$

Chen, C.-C., R. Raskin and D.R. Tebbets, Products of graduate library and information science schools: untapped resources?

(3) $163-190$

Cronin, B., Information technology and information management: strategies for post-experience training

(2) $79-94$

Evans, G.E., Management education for archivists, information managers, and librarians: is there a global core?

(4) $295-307$

Farrow, C., Proposed changes in library and information science education in the Netherlands (Short Communication)

(1) $43-50$

Farrow, C., How the Dutch Schools of Library and Information Science chose their automation facilities (Short Communication)

(3) $229-234$

Gray, R., Legal research education: the challenge to British law schools

(4) $283-293$

Jackson, M.M., Convergence: the new information science (Short Communication)

(4) 309-311

Mangla, P.B., Research in library and information science and the contribution of Ranganathan

(4) $267-282$

Neelameghan, A., International and regional cooperation in human resource development for information services in developing countries: a case study

(3) $191-208$

Raskin, R., see C.-C. Chen

(3) $163-190$

Schlessinger, B.S. and J.H. Schlessinger, The use of microcomputers in education for librarianship and information science

(1) $29-34$

Schlessinger, J.H., see B.S. Schlessinger

(1) $29-34$

Scott, A.D., Mini- and micro-computers in education and training for library and information work

(2) 109-115

Tebbetts, D.R., see C.-C. Chen

(3) $163-190$

Van Wye, R.H., New requirements for information professionals in librarianship (Short Communication)

(2) $123-125$ 
Wasserman, P., Review of international and regional programmes in training managers for the information profession

(1) $3-18$

Wolters, E., Education of librarians and documentalists in information processing techniques

(2) $117-122$

Zaaiman, R.B., Differences in educational programmes for librarians and information officers

(2) $95-108$ 